\title{
THE GREAT INOGULATOR
}




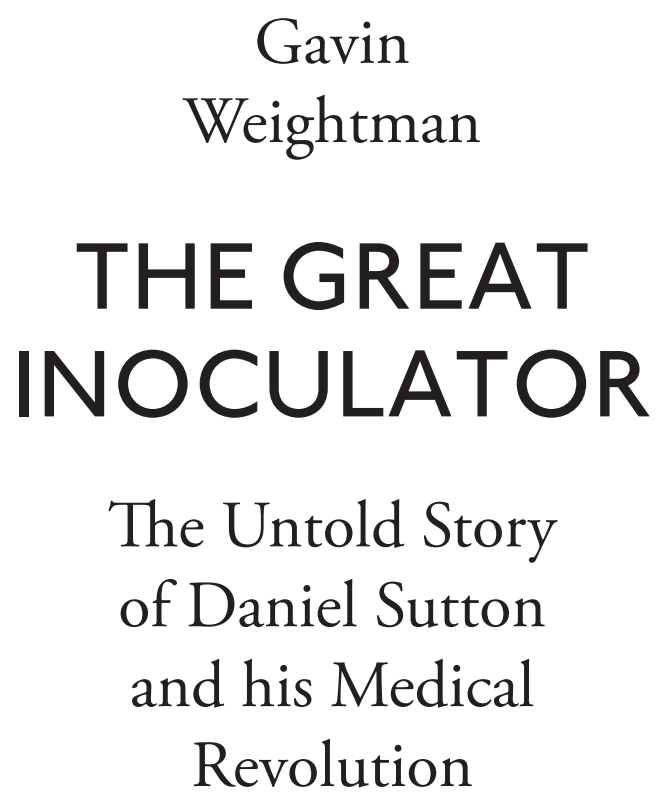

YALE UNIVERSITY PRESS NEW HAVEN AND LONDON 
Published with assistance from the Annie Burr Lewis Fund.

\section{Copyright (c) 2020 Gavin Weightman}

All rights reserved. This book may not be reproduced in whole or in part, in any form (beyond that copying permitted by Sections 107 and 108 of the U.S. Copyright Law and except by reviewers for the public press) without written permission from the publishers.

For information about this and other Yale University Press publications, please contact: U.S. Office: sales.press@yale.edu yalebooks.com Europe Office: sales@yaleup.co.uk yalebooks.co.uk

Set in Minion Pro by IDSUK (DataConnection) Ltd

Printed in Great Britain by TJ International Ltd, Padstow, Cornwall

Library of Congress Control Number: 2020938180

ISBN 978-0-300-24144-0

A catalogue record for this book is available from the British Library.

10987654321 